\title{
Relationship between body mass index and body condition score in Pelibuey
}

\section{ewes}

\section{Relación entre el índice de masa corporal y condición corporal en ovejas Pelibuey}

Eufracia del R. Salazar-Cuytun ${ }^{1,2}$ (1) Alfonso J. Chay-Canul $2 *$ D

Martin Ptáček

Ricardo A. Garcia-Herrera2 2

Flor de Maria Rivera-Alegria 4 [D

Armando J. Aguilar-Caballero D

Luis A. Sarmiento-Franco 1 [D

${ }^{1}$ Facultad de Medicina Veterinaria y Zootecnia, Universidad Autónoma de Yucatán. Carr. Mérida-Xmatkuil km 15.5, Apdo. 4-116 Itzimná, CP. 97100, Mérida, Yucatán, México.

${ }^{2}$ División Académica de Ciencias Agropecuarias, Universidad Juárez Autónoma de Tabasco. Carretera Villahermosa-Teapa, km 25, R/A. La Huasteca $2^{a}$ Sección, CP. 86280 , Villahermosa, Tabasco, México.

${ }^{3}$ Department of Animal Science, Faculty of Agrobiology, Food and Natural Resources, Czech University of Life Sciences Prague, Kamýcká 129, 16500 Prague - Suchdol, Czech Republic.

${ }^{4}$ Departamento de Ingeniería Bioquímica. Escuela Nacional de Ciencias Biológicas, Instituto Politécnico Nacional. Av. Wilfrido Massieu s/n, esq. Manuel L. Stampa, Gustavo A. Madero, CP. 07738. Ciudad de México, México.

*Corresponding author: aljuch@hotmail.com

Scientific note

Received: november 23, 2019 Accepted: april 23, 2020

How to cite: Salazar-Cuytun E del R, Chay-Canul AJ, Ptáček M, Garcia-Herrera RA, Rivera-Alegria $\mathrm{F}$ de $\mathrm{M}$, Aguilar-Caballero AJ, Sarmiento-Franco LA (2020) Relationship between body mass index and body condition score in Pelibuey ewes. Ecosistemas y Recursos Agropecuarios 7(2): e2474. DOI: 10.19136/era.a7n2.2474
ABSTRACT. The objective of the current study was to relate body mass index (BMI) and body condition score (BCS) in Pelibuey ewes in order to predict BMI based on a well-known method for estimating BCS. Body weight $(\mathrm{BW})$, withers height $(\mathrm{WH})$, body length $(\mathrm{BL})$ and $\mathrm{BCS}$ were measured in 402 ewes. The relationships were investigated by regression models. The $\mathrm{BMI}$ and BCS had a strong relationship $(r=0.80, p<0.001)$. The linear regression for predicting BMI from BCS was as follows: BMI $\left(\mathrm{kg} \mathrm{m}^{-2}\right)=$ $8.38\left( \pm 0.189^{\star \star \star}\right)+1.70\left( \pm 0.064^{\star \star \star}\right) \times B C S\left(R^{2}=0.65\right.$, MSE: 2.56 , RMSE: $1.60, p<0.0001$ and $n=402$ ). In conclusion, BMI can be used as an indicator of the degree of obesity and body fat reserves in non-pregnant and non-lactating Pelibuey ewes under field conditions.

Key words: Body mass index, body measurements, body fat, energy reserves.

RESUMEN. El objetivo de este estudio fue evaluar la relación entre el índice de masa corporal (IMC) y la condición corporal (CC) en ovejas Pelibuey y predecir el IMC según una estimación conocida de la CC. El peso corporal (PV), la altura de la cruz, (AC), la longitud del cuerpo (LC) y la CC se determinaron en 402 ovejas. Las relaciones se estimaron mediante modelos de regresión. EI IMC y la CC mostraron una alta relación $(r=0.80$, $\mathrm{p}<0.001)$. La regresión lineal para la predicción del IMC fue la siguiente: IMC $\left(\mathrm{kg} \mathrm{m}^{-2}\right)=8.38\left( \pm 0.189^{* * *}\right)+1.70\left( \pm 0.064^{* * *}\right) \times C C\left(R^{2}=0.65\right.$, MSE: 2.56, RMSE: $1.60, \mathrm{p}<.0001$ y $\mathrm{n}=402$ ). EI IMC podría usarse como un indicador del grado de obesidad y de las reservas corporales de grasa en ovejas Pelibuey no gestantes y no lactantes en condiciones de campo.

Palabras clave: Indice de masa corporal, medidas corporales, grasa corporal, reservas de energía. 


\section{INTRODUCTION}

Body condition scores (BCS) are used to evaluate subcutaneous fat and muscular reserves along the spine of domestic animals (Kenyon et al. 2014). In particular, they have been used alongside live weight (LW) to estimate fat and muscle reserves in sheep in vivo since the 1960s (Phythian et al. 2011, Kenyon et al. 2014). These indicators are important for nutritional and livestock management strategies to improve productive and reproductive parameters (Morley et al. 2014, Kenyon et al. 2014) because they reflect body energy reserves (Chay-Canul et al. 2011).

However, BCS estimation has been called into question for animals that accumulate most of their reserves in the abdominal cavity, such as sheep. In particular, Pelibuey sheep show great variation in fat depots because they accumulate a large proportion of total fat in their internal cavity (Chay-Canul et al. 2011). Moreover, BCS is considered a subjective measurement of body energy reserves. For instance, McHugh et al. (2018) argued that BCS is a subjective evaluation of body energy reserves in animals and that the amount of reserves is independent of frame size. Even so, BCS have been widely adopted because they are easy to determine under field conditions (Kenyon et al. 2014, Randby et al. 2015). For this reason, estimating of alternative nutritional status attributes to commonly used BCS are in scope of interest for this breed.

In animals that accumulate reserves internally, it is also necessary to consider LW, which reflects both body size and condition. Even so, a particular LW could be associated with a large animal in poor condition or small animal in very good condition (Kenyon et al. 2014). For this reason, BCS are not entirely adequate for evaluating internal fat reserves despite their extensive use.

On the other hand, body mass (LW) and body dimension (height) are commonly used in humans to determine body mass index (BMI) with a high degree of accuracy (Burton 2007). Specifically, BMI is calculated as body mass $(\mathrm{kg}) /$ height $^{-2}(\mathrm{~m})$ and is used as an indicator of energy status (Tanaka et al. 2002,
Burton 2007). Different authors have defined which BMI ranges indicating malnutrition $\left(<16.0 \mathrm{~kg} \mathrm{~m}^{-2}\right)$ and obesity (> $34 \mathrm{~kg} \mathrm{~m}^{-2}$ ) (Okorodudu et al. 2010, Doak et al. 2013). Current worldwide guidelines define overweight as a BMl of $25-29.9 \mathrm{~kg} \mathrm{~m}^{-2}$ and obesity as a BMI of $30 \mathrm{~kg} \mathrm{~m}^{-2}$ or higher.

Recently, BMI has been adapted for use as an indirect estimator of fat accumulation in domestic animals (Vilar-Martinez et al. 2009, Chavarría-Aguilar et al. 2016, Liu et al. 2019). Chavarría-Aguilar et al. (2016) reported that BMI had a strong relationship with body energy reserves in sheep and can hence be used as a predictor of energy reserves in mature Pelibuey ewes. Additionally, the relationship of BMI with the concentration of hormones related to energy metabolism and reproduction activity in goats has been studied (Tanaka et al. 2002, Habibu et al. 2016).

However, it is not clear how BMI and BCS are related. Only limited information is available on their association. In one case, Chavarria-Aguilar et al. (2016) reported a positive relationship between BMI and BCS $(r=0.80)$ in hair ewes. However, Ptáček et al. (2018) found only a minor association. At the same time, there is a growing interest in new approaches for calculating the body energy reserves of livestock for management purposes, especially for maternal hair sheep breeds in Mexico. Therefore, the objective of the current study was to define the relationship between BMI and BCS in multiparous Pelibuey ewes and to then explore the possibility of using BMI as an easier way of estimating BCS. Also, the BMI ranges for different levels of body fat reserves were established and related with specific BCS.

\section{MATERIALS AND METHODS}

\section{Animals, handling and feeding}

Animals were treated in accordance with the guidelines and regulations for animal experimentation of the Department of Agricultural and Livestock Sciences (División Académica de Ciencias Agropecuarias) of the Autonomous Juárez University of Tabasco (Universidad Juárez Autónoma de Tabasco). 
Data on body weight (BW), body condition (BCS), withers height $(\mathrm{WH})$ and body length $(\mathrm{BL})$ were collected from 402 non-pregnant and non-lactating Pelibuey ewes aged 2 to 4 years. Animals were selected from the El Rodeo Farm located at km 14 along the Villahermosa-Jalapa highway in the Rancheria Victor Manuel Fernández Manero in Jalapa, Tabasco. The BCS was determined using a 5-point scale, where 1 corresponded with very thin (emaciated) and 5 with obese (Russell et al. 1969). The BMI was calculated as follows: $B M I=[B W(k g) / W H(m) / B L(m)] /$ 10 (Tanaka et al. 2012).

$\mathrm{BL}$ was measured as the distance between the dorsal point of the scapulae and the ventral point of the tuber coxae. WH was measured from the highest point of the scapulae vertically to the ground (Bautista-Diaz et al. 2017). BW was recorded with a digital balance.

The ewes were confined in a roofed building with a concrete floor without walls. The diet consisted in $66 \%$ forage and $34 \%$ concentrate, with an estimated metabolisable energy of $12 \mathrm{MJ} / \mathrm{kg}$ dry matter and $10 \%$ crude protein (AFRC 1993). The ingredients in the diet were cereal grains (maize or sorghum), soybean meal, tropical grass hay and vitamins and minerals.

\section{Statistical analyses}

Descriptive statistics were calculated using PROC MEANS in SAS. The correlation coefficients were estimated with PROC CORR in SAS and tested as values different from zero. The REG procedure (SAS 2010) was used to determine the linear regressions between BMI and BCS. ANOVAs were carried out to evaluate the influence of a particular BCS (BCS 1, $n=115$; BCS 2, $n=102$; BCS 3, $n=82$; BCS $4, n=55$; BCS $5, n=48$ ) on BMI. Additionally, the animals were grouped according to their BCS in three categories: light (BCS: $1 \leq 2, n=217$ ), medium (BCS: $>2 \leq 3.5, n=81$ ) and heavy (BCS: $\geq 4, n$ $=104)$. The BMI ranges associated with the BCS categories were determined by ANOVAs. Finally, the effect of BCS on BMI was tested at a significance level of $p<0.05$.

\section{RESULTS AND DISCUSSION}

The basic statistics are presented in Table 1 and indicate a high variability in the data, especially in BCS (Monteiro et al. 2010, Phythian et al. 2011). Even so, BCS is a useful management tool in many ruminant livestock production systems. The subjectivity of the measure is not of great concern if assessments are consistent, although inaccurate BCS estimates are more likely for ruminant dairy animals compared to breeds raised primarily for meat due to the growth pattern of the main body fat depots (Eknas et al. 2017, Liu et al. 2019). For this reason, some researchers have adapted the use of BMI rather than or in addition to BCS in the search for a more objective and easily applied means of monitoring the nutritional status of domestic animals (Vilar-Martinez et al. 2009, Liu et al. 2019).

In humans, BMI is widely used as an indicator of energy status and degree of obesity (Tanaka et al. 2002, Ortega et al. 2016). Several studies have also considered the BMI as an energy status indicator for different livestock (Monteiro et al. 2010, ChavarríaAguilar et al. 2016, Randby et al. 2015, Habidu et al. 2017, Liu et al. 2019), with recent studies confirming the potential of BMI as an alternative to BCS for flock management (Ptáček et al. 2018). The present study also confirms this potential, as BCS and BMI had a strong relationship with a correlation coefficient $(r)$ of $0.80(p<0.001)$, similar to the results of ChavarríaAguilar et al. (2016). The BMI ranges associated with particular BCS scores are shown in Figure 1. Significant differences $(p<0.05)$ were found in BMI with respect to BCS. The lowest BMI of $10.30 \pm 0.149$ $\mathrm{kg} \mathrm{m}^{-2}$ was found for a BCS of 1 , and the highest BMI of $16.95 \pm 0.264 \mathrm{~kg} \mathrm{~m}^{-2}$ was found for a BCS of 5 .

To further the prediction ability of BMI, a linear regression was carried out, resulting in the following equation: $\mathrm{BMI}\left(\mathrm{kg} \mathrm{m}^{-2}\right)=8.38\left( \pm 0.189^{\star \star \star}\right)+1.70$ $\left( \pm 0.064^{\star \star \star}\right) \times$ BCS $\left(R^{2}=0.65\right.$, MSE: 2.516; RMSE: 1.586; $p<.0001$ and $n=402$; Figure 2). Ptáček et al. (2018) found a stronger relationship between BMI and fat or muscle deposits compared to the present study despite noting a moderate but positive trend between $\mathrm{BMI}$ and BCS. Specifically, in the present study, ewes 
Table 1. Descriptive analysis of data $(n=402)$

\begin{tabular}{lllll}
\hline Variable & Description & Mean \pm SE & Maximum & Minimum \\
\hline BCS & Body condition score & $2.71 \pm 1.31$ & 5.00 & 1.00 \\
BW & Body weight $(\mathrm{kg})$ & $43.1 \pm 10.05$ & 75.00 & 20.00 \\
BMI & Body mass index $\left(\mathrm{kg} \mathrm{m}^{-2}\right)$ & $13.08 \pm 2.87$ & 22.57 & 7.20
\end{tabular}

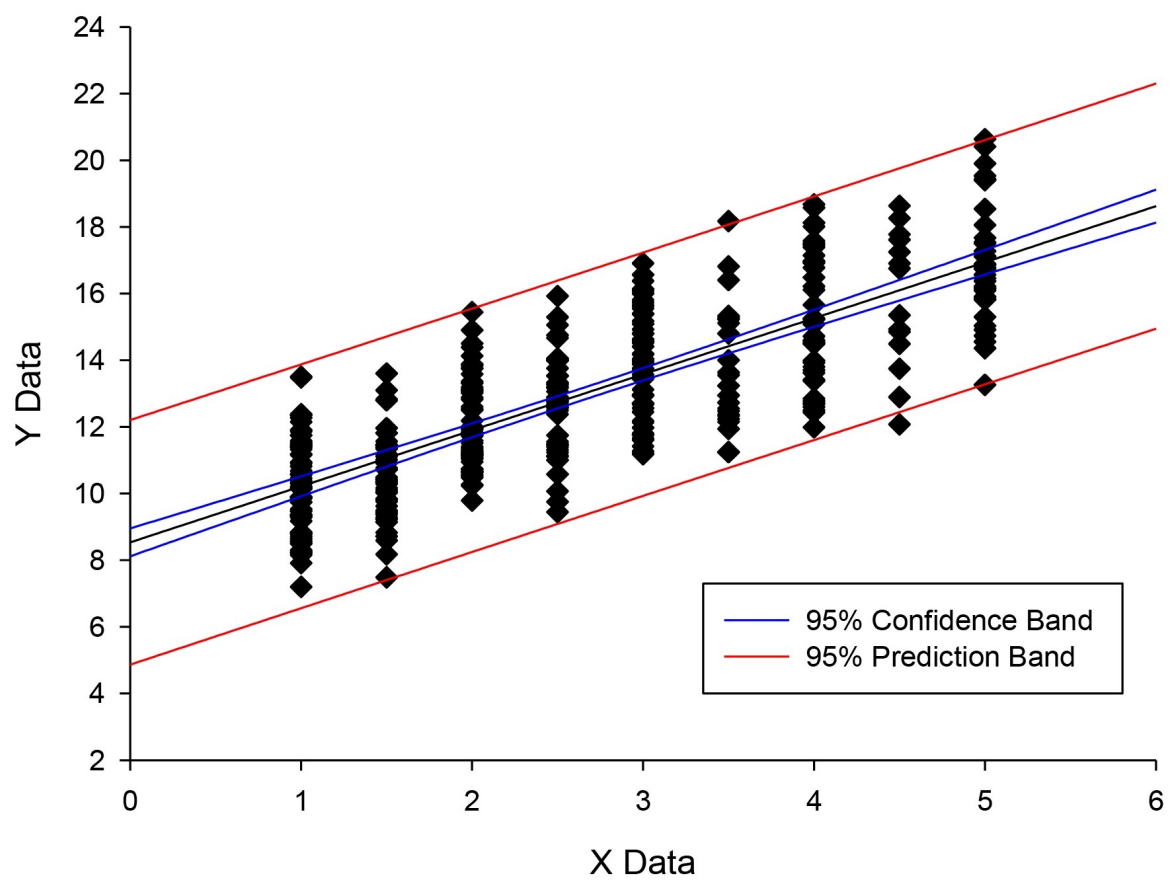

Figure 1. Linear regression between body mass index (BMI) and body condition score (BCS) in Pelibuey ewes: BMI $\left(\mathrm{kg} \mathrm{m}^{-2}\right)=8.38\left( \pm 0.189^{\star \star \star}\right)+1.70\left( \pm 0.064^{\star \star \star}\right) \times$ BCS $\left(R^{2}=0.65\right.$, MSE: 2.56; RMSE: 1.60; $\mathrm{p}<0.0001$ and $\mathrm{n}=402) .{ }^{\star * \star}=\mathrm{p}<0.05$. X Data $=\mathrm{BCS} ; \mathrm{Y}$ Data $=$ BMI.

categorised as light (BCS = 1<2) had a BMl of $11.23 \pm 0.121 \mathrm{~kg} \mathrm{~m}^{-2}$ ), whereas those categorised as medium $(\mathrm{BCS}>2<3.5)$ and heavy $(\mathrm{BCS}>4)$ had a BMI of $13.76 \pm 0.203 \mathrm{~kg} \mathrm{~m}^{-2}$ and $16.00 \pm 0.186$ $\mathrm{kg} \mathrm{m}^{-2}$, respectively (Figure 3 ).

In prepubertal ewe lambs, Monteiro et al. (2010) found a rather low correlation $(r)$ of $0.20(p=$ $0.0019)$ between BCS and BMI since BMI increased while BCS was maintained. These latter authors highlighted the need to determine with greater precision the relationship between BMI and age of puberty onset in future works. Although some methods such as biometric measurements, including BCS and BW, have been used to predict body composition in cattle and sheep, it is still necessary to find more precise approaches to determining body energy reserves and body chemical composition in domestic animals. For example, little information exists on the relationship between BMI and body chemical composition, even though the BMI involves measuring the body mass and size/frame-size of animals.

On the other hand, Okorodudu et al. (2010) examined the combined results of 32 studies and concluded that BMI can be used to identify excessive adiposity with good specificity but low sensitivity (around 50\%). Also, Liu et al. (2019) found stronger relationships between performance measures and BMI rather than BCS in doelings. These authors concluded that future research should address the relationships between BMI and other physiological states and production conditions.

The current study presents preliminary results on the use of BMI as an indicator of the degree of fatness in Pelibuey sheep, including the BMI ranges 


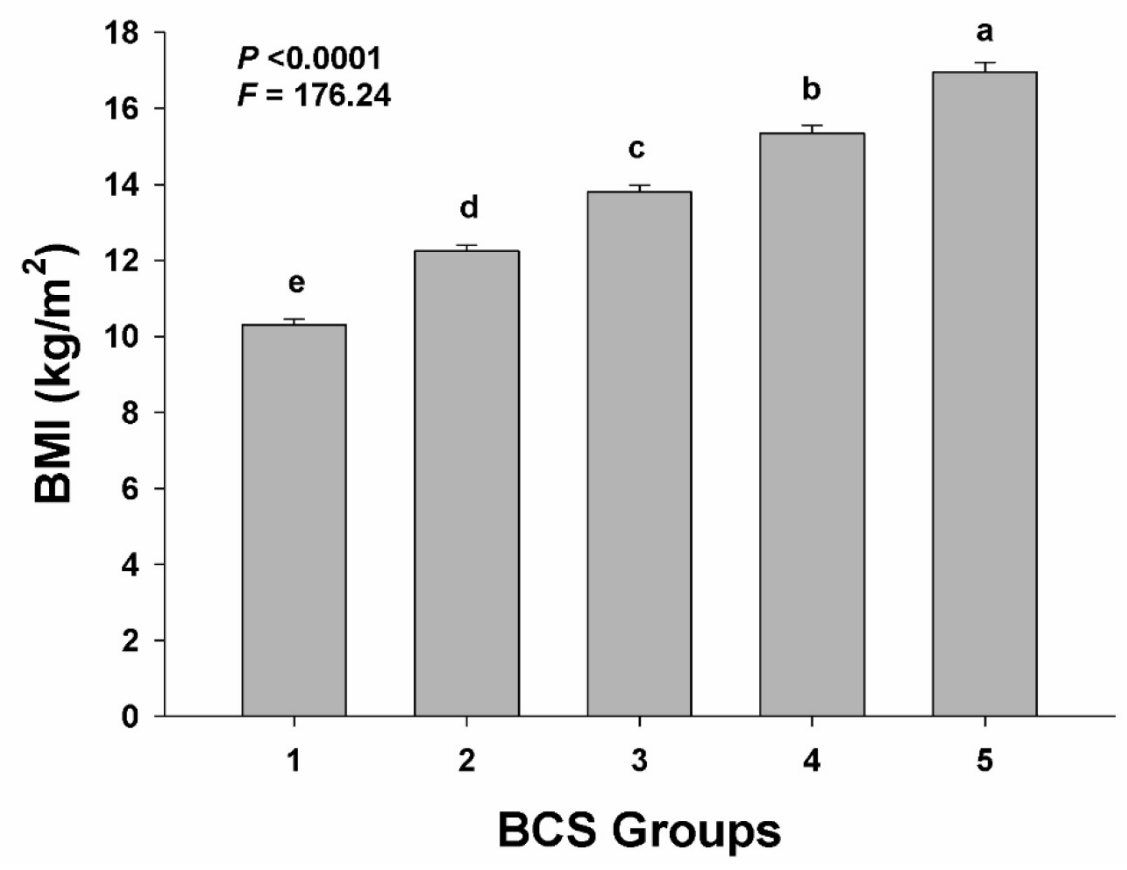

Figure 2. BMI ranges in Pelibuey ewes related to BCS (mean \pm standard error): 1) $10.52 \pm$ 0.267 ; 2) $12.32 \pm 0.210$; 3) $14.06 \pm 0.213$; 4) $15.42 \pm 0.260$ and 5) $16.87 \pm 0.278 \mathrm{~kg} \mathrm{~m}^{-2}$. Different letters $(a, b, c, d, e)$ among columns indicate significant differences $(p<0.05)$.

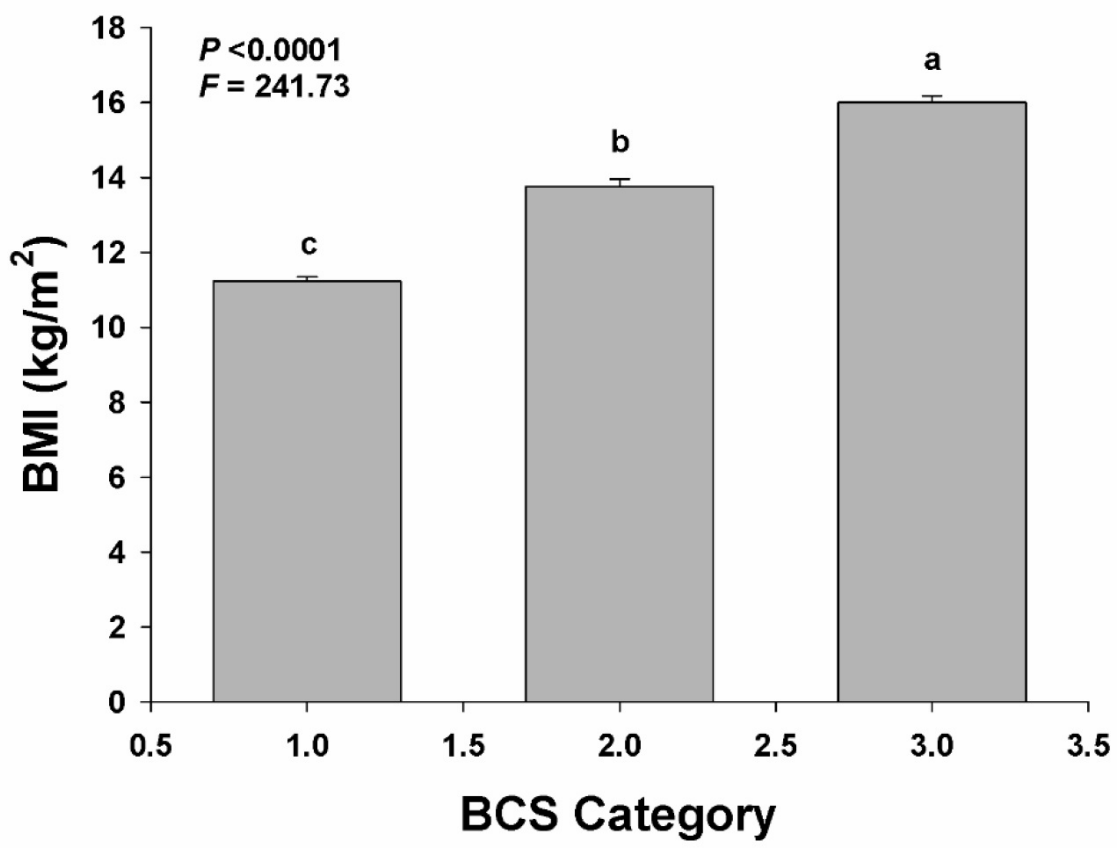

Figure 3. BMI ranges in Pelibuey ewes related to BCS categories (mean \pm standard error): 1) light $\left(11,635 \pm 0.175 \mathrm{~kg} \mathrm{~m}^{-2}\right)$, 2) medium $\left(14,031 \pm 0,227 \mathrm{~kg} \mathrm{~m}^{-2}\right)$ and 3) heavy $(16,110 \pm$ $\left.0.200 \mathrm{~kg} \mathrm{~m}^{-2}\right)$. Different letters (a, b, c, d, e) among columns indicate significant differences $(\mathrm{p}<$ 0.05). 
associated with specific BCS. It is worthwhile to continue to explore the relationship between BMI and energy balance, body composition and reproductive performance and productivity in tropical hair sheep given its ease of calculation. Also, it is necessary to validate the $\mathrm{BMI}$ rangescorresponding with different production or physiological stages. In conclusion, given the strong relationship between BMI and BCS, BMI could be used as an indicator of the degree of obesity and body fat reserves in adult, non-pregnant and non-lactating Pelibuey ewes. Futures studies should further examine the use the BMI as predictor of body composition in sheep in different physiological states.

\section{ACKNOWLEDGEMENTS}

The authors thank Dr. Jose Manuel Piña Gutierrez for granting access to the facilities of El Rodeo Ranch.

\section{LITERATURE CITED}

AFRC (1993) Energy and Protein Requirements of Ruminants. Agricultural and Food Research Council. CAB International. Wallingford, UK. 159p.

Burton RF (2007) Why is the body mass index calculated as mass $/$ height $^{2}$, not as mass $/$ height $^{3}$ ? Annales of Human Biology 34: 656-663.

Bautista-Díaz E, Salazar-Cuytun ER, Chay-Canul AJ, García-Herrera RA, Piñeiro-Vázquez AT, Magaña-Monforte JG, Tedeschi LO, Cruz-Hernández A, Gómez-Vázquez A (2017) Determination of carcass traits in Pelibuey ewes using biometric measurements. Small Ruminant Research 147: 115-119.

Chavarría-Aguilar LM, García-Herrera RA, Salazar-Cuytun R, Chay-Canul AJ, Casanova-Lugo F, Piñeiro-Vázquez AT, Aguilar-Caballero AJ (2016) Relationship between body fat depots and body mass index in Pelibuey. Small Ruminant Research 141: 124-126.

Chay-Canul AJ, Ayala-Burgos AJ, Kú-Vera JC, Magaña-Monforte JG, Tedeschi LO (2011) The effects of metabolizable energy intake on body fat depots of adult Pelibuey ewes fed roughage diets under tropical conditions. Tropical Animal Health and Production 43: 929-936.

Doak C M, Hoffman D J, Norris SA, Ponce M C, Polman K, Griffiths PI (2103) Is body mass index an appropiate proxy for body fat in children? Global Food Security 2: 65-71.

Eknas M, Chilliard Y, Hove K, Inglingstad R A, Bernard L, Volden H (2017) Feeding of palm oil fatty acids or rapeseed oil throughout lactation: Effects on energy status, body composition, and milk production in Norwegian dairy goats. Journal of Dairy Science 100: 7588-7601.

Habibu B, Kawu MU, Makun HJ Aluwong T, Yaqub LS (2016) Seasonal variation in body mass index, cardinal physiological variables and serum thyroid hormones profiles in relation to susceptibility to thermal stress in goat kids. Small Ruminant Research 145: 20-27

Kenyon PR, Maloney SK, Blache D (2014) Review of sheep body condition score in relation to production characteristics. New Zealand Journal of Agricultural Research 57: 38-64.

Liu H, Gipson TA, Puchala R, Goetsch AL (2019) Relationships among body condition score, linear measures, body mass indexes, and growth performance of yearling Alpine doelings consuming high-forage diets. Applied Animal Science 35: 511-520. 
McHugh N, McGovern F, Creighton P, Pabiou T, McDermott K, Wall E, Berry DP (2019) Mean difference in liveweight per incremental difference in body condition score estimated in multiple sheep breeds and crossbreds. Animal 13: 549-5531.

Monteiro CD, Bicudo SD, Toma HS, Biscarde CEA, Oliveira TM, Falleiros MB, Bicudo LC, Magalhães, LCO (2010) Medroxyprogesterone acetate or long-acting progesterone in the biostimulation of lambs. Italian Journal of Animal Science 9: 344-347

Morley SA, Murray JA (2014) Effects of body condition score on the reproductive physiology of the broodmare: a review. Journal of Equine Veterinary Science 34: 842-853.

Okorodudu DO, Jumean MF, Montori VM, Romero-Corral A, Somers VK, Erwin PJ, Lopez-Jimenez F (2010) Diagnostic performance of body mass index to identify obesity as defined by body adiposity: a systematic review and meta-analysis. International Journal of Obesity 34: 791-799.

Ortega FB, Sui X, Lavie CJ, Blair SN (2016) Body-mass index, the most widely used but also widely criticized index: would a criterion standard measure of total body fat be a better predictor of cardiovascular disease mortality? Mayo Clinical Procedings 91: 443-455.

Phythian CJ, Hughes D, Michalopoulou E, Cripps PJ, Duncan JS (2011) Reliability of body condition scoring of sheep for cross-farm assessments. Small Ruminant Research 104: 156-162.

Ptáček M, Milerski M, Schmidová J, Ducháček J, Tančin V, Uhrinča? M, Hakl J, Stádník L (2018) Relationship between body mass index, body energy reserves, milk, and meat production of original Wallachian sheep. Small Ruminant Research 165: 131-133.

Randby AT, Borodina S, Dønnem I (2015) Effect of body mass index at parturition on goat milk quality and yield. Animal Production Science 55: 231-236.

Russel AJF, Doney JM, Gunn RG (1969) Subjective assessment of body fat in live sheep. Journal of Agricultural Science 72: 451-454.

SAS (2010) SAS, 9.3 Software. Institute Inc., Cary, North Carolina, USA.

Tanaka T, Akaboshi N, Inoue Y, Kamomae H, Kaneda Y (2002) Fasting-induced suppression of pulsatile luteinizing hormone secretion is related to body energy status in ovariectomized goats. Animal Reproduction Science 72: 185-196.

Tanaka T, Akaboshi N, Inoue Y, Kamomae H, Kaneda Y (2012) Corrigendum to "Fasting-induced suppression of pulsatile luteinizing hormone secretion is related to body energy status in ovariectomized goats". Animal Reproduction Science 132: 111.

Vilar-Martinez H, Vera-Avila HR, Gonzalez-Padilla E, Lopez-Ordaz R, Dominguez-Araujo G, Jimenez-Severiano $\mathrm{H}$, Mejia-Guadarrama C (2009) Comparison of different in vivo estimators of body fat and muscle content in adult creole goats. Tropical and Subtropcal Agroecosystems 11: 95-97. 